International Journal of Student Research 1(2018) 8-12

Contents lists available at ScienceCite

International Journal of Student Research

journal homepage:

http://scopuseu.com/scopus/index.php/ijsr/index

\title{
The role of identity in contemporary European society
}

Alena Victorovna Abramova*

Saint-Petersburg State University, the School of International Relations, Saint-Petersburg, Russia

\section{ARTICLE INFO ABSTRACT}

Article history:

Received 20 November 2018

Accepted 23 November 2018

Available online 02 December 2018

JEL classifications: No
The issue of identity is one of the most significant in the contemporary discourse of the European Union. The creation of a united European society, undoubtedly, assumes the presence of shared values, ideas, viewpoints among its members. Together, these elements create a perception of identity. The question of whether a European identity is necessary is very controversial and provides a broad field for research.

(C) 2018 The Author. Published by OEAPS Inc.

This is an open access article under the CC BY-NC-ND

license (http://creativecommons.org/licenses/by-nc-nd/4.0/).

*Corresponding author.E-mail address: alyona24101997@yandex.ru

Peer-reviewed Publication DOI CROSS REF doi: 
Discussion of the role of identity for European society is meaningless without understanding the definition of the category of "identity". There are many descriptions of this notion. For example, Hogg and Abrams explain it as "people's ideas of who they are, of what sort of people they are, and how they compare to others". (Hogg and Abrams, 1988). According to F. Deng "identity is the way individuals and groups define themselves and are defined by others on the basis of race, ethnicity, religion, language, and culture". (Deng, 1995). Another interpretation is given by R. Jenkins. He describes identity as "the models in which individuals and collectivities are distinguished in their social relations with other individuals and collectivities». (Jenkins, 1996).

Although above definitions are quite similar, nowadays, in the context of globalization, it is still hard to define what identity is and how it is determined. The German philosopher Georg Hegel wrote: "Only a state which is sovereign relative to other states can be independent. This independence is necessary for the society to form its identity within the state". (Hegel, 1990, p.365). Despite the fact that these words were said several decades ago, they have not lost their significance. On the other hand, in the modern world, the identity of a society and an individual cannot be limited by the concept of a national state, as identity includes not only a sense of belonging to an ethnic community. According to another German philosopher JurgenHabermas, "globalization finally unleashed citizenship from national identity". (Habermas, 1999, p.34). Thus, the issue of identity is pretty debatable in general. What is European identity and what is its role in the further development of the Union? Can it be argued that the desire to create an artificial sense of unity is an attempt to resist the growing influence of the US and China? How will the presence or absence of identity affect the process of integration in the European Union? All these and many other questions arise during the discussion on the topic of European identity. Despite the fact the European Union has a long history, European identity has not developed as something definite during these years. Consequently, the question about its necessity remains to be controversial.

For the EU, the idea of European identity is crucial. European identity is necessary for the European Union to withdraw fragmentation, chaos and all types of conflicts (military, social, economic and political) and to promote unity, solidarity, harmony and cooperation. However, nowadays identity is a dual problem for the EU. Firstly, there is a demand for identity at the Union level. This identity should be clear and unambiguous both in the EU and outside its borders. Secondly, it is necessary to integrate the idea of Europe not only at the political and economic levels but also at the level of existing national identities. (Berendeev, 2012 , p.77). Thus, the question is rather what identity is more necessary -European or national, than whether European identity is necessary or not.

In modern Europe, almost no one can provide a comprehensive answer to the question of what is a European identity. What does this elusive term include? Daniel Tarshis, the Secretary-General of the Council of Europe, defines European identity as "a very strong commitment to individualism, to social coherence and to solidarity. Respect to human rights, sense of tolerance and equality. The rule of law, the idea of state accountability". Mark Leonard, an author of the "Demos Research Centre" report, explains that identity is constructed on the basis of everyday commonalities. In his opinion, Europeans are united by the shared attitudes to consumption patterns and lifestyle: visiting the same places, eating the same food, watching the same movies. The Vice-President of the European Commission Leon Brittan considers that a sense of identity cannot be imposed, it develops little by little over decades. If Europe is open to the world, well-managed and attentive to its citizens, people will feel the emotional connection with such Europe and the desire to be a part 
of it. At the same time, he states that there is always a room for national identity, because it remains to be a basis for self-determination for most of the people. (Partos, BBC World Service).

However, it is simple to declare that European identity should be based on common values, but is there a sense of common European unity that can bind people together in every time? (Debating Europe, 2013). In 2017 and 2018, the polls conducted by Project 28 registered that $51 \%$ of respondents believe that individual nations should have more sovereignty within the EU, while only $35 \%$ voted for strengthening integration. (Project 28, 2018). Thus, the feeling of national identity prevails over the artificial category of Europeanness. It is seen through the example of Scotland, tried to leave Great Britain in 2014 and 2016. It is also revealed in an expansion of nationalism and populism in Catalonia, where a referendum on withdrawal took place last year. Brexit also might be seen not only as an economic issue but as a denial of European identity as well. (Debating Europe, 2017)

The issue of national identity was one of those Europeans hoped to avoid during the first decades after World War II. The project of the European Union assumed a rejection of national selfishness and antagonisms defining European policy in the 20th century. A new universal European identity was supposed to displace old Italian, German or French identities. Nowadays, the idea of European identity is incompatible since the old identities have not disappeared. Citizens of European countries have never forgotten they are Germans, Dutch, French or Italian. The diversity of identities within the European community has become a real dilemma with the migration crisis and the increase of the number of representatives of other communities which are different from and often alien to traditional European values. (Fukuyama, 2012).

The European Union was originally established to achieve economic efficiency. Over time, it was recognized that common economic aims were not enough to unite people at the subconscious level and turn them into one society. In this regard, Fukuyama's statement has a point. In his opinion, rich Germans feel responsible towards Germans with low income. Thus, social solidarity is a basis of the German welfare state. However, Germans do not feel the same towards Greeks, who are considered as quite careless about financial matters. Although they all are members of one system named European Union, Germans do not think they are to solve Greeks' or other nations' problems within the Union. (Fukuyama, 2012). Thus, the economic and migration crises revealed the lack of cohesion still taking place within the Union. They undermined the unified European home. (Berendeev, 2012, p.77).

Developing the European identity became more complicated following an extension in the number of member states. Especially for the countries which were quite different from the first EU members from economic, cultural and political points of view. Thus, the expansion of the Union automatically led to a slowdown in European identity development. (Berendeev, 2012, p.77). On the other hand, reaction to the idea of Turkey's entry to the Union showed the existence of unity. $73 \%$ of respondents did not approve this plan. (Project 28, 2018).

Consequently, even if European identity is not established as a specific category, non-European identity is clear for most of EU citizens.Despite the fact, that European politicians discuss common identity as an almost real phenomenon, there is a lack of this identity in modern European society. At the economic and political levels, cohesion is still observed, although above mentioned crises have caused serious contradictions. At the social level, there is a definite necessity for connecting links which could provide the development of European integrity. (Fedortsev, Mamedova, 2011).

The issue of European identity is complicated and contradictory for three main reasons. First of all, for 
centuries Europe has been an open and multifaceted environment where multiple cultural identities met. It is a reason for many researchers to discuss European identity in the plural form.Secondly, Europeans keep the different historical memory. The purest example is wars. The victory of one state always involves the defeat of another one. Austerlitz is celebrated in Paris; Trafalgar is celebrated in London. Moreover, Europeans speak different languages. Thus, there is no such an important component as a linguistic commonality. Thirdly, European culture has become an indispensable part of modernity. It spread all over the world and included elements of other cultures. As a consequence, some researchers believe that now it is challenging or even impossible to define European identity. (Martinelli, 2017, p.3).

Nowadays national identity remains to prevail over a sense of belonging to European society for most EU citizens. Despite the fact that the European Union has existed for many years, its citizens still consider European identity as something tangential and unclear. European identity is a constructed artificial category. There is no guarantee that people would accept it. The chance they would replace their national identity with the European one is even smaller. It can be explained by the fact that since the moment of foundation the European Union has been focused on economic integration rather than on social or cultural. However, common economic aims were not enough to build a consolidated society. Therefore, if a lack of a common identity is considered as an obstacle to comprehensive integration, the European identity is necessary. Therefore, the development of such an identity should become a principal task for the EU government.

\section{References:}

1. Berendeev, M. 2012. "European identity" today: the category of political practice or discourse? Scientific journal of the Baltic Federal University named after I. Kant.

2. Deng, Francis M. 1995. War of Visions: Conflict of Identities in the Sudan. Washington, DC: Brookings.

3. Fedortsev, V; Mamedova, L. 2011. The European Union: searching for a "European identity". Scientific Journal "Problems of the national strategy", №4 (9)

4. Habermas, J. 1999. Searching for National Identity. Philosophical and political articles. Donetsk

5. Hegel, G. 1990. Philosophy of law. Moscow

6. Hogg, Michael and Dominic Abrams. 1988. Social Identifications: A Social Psychology of Intergroup Relations and Group Processes. London: Routledge.

7. Jenkins, Richard. 1996. Social Identity. London: Routledge.

8. Partos, G. Identity: How European do people feel? BBC World Service. Retrieved on 02.06.2018 from: http://www.bbc.co.uk/worldservice/theneweurope/wk17.htm 
9. Fukuyama, F. January11, 2012. The Challenges for European Identity. The Global Journal. Retrieved on 02.06.2018 from: http://theglobaljournal.net/article/view/469/

10. Debating Europe. October 4, 2017. Can the EU survive without a common European identity? Retrieved on 02.06.2018 from: http://www.debatingeurope.eu/2017/10/04/can-eu-survive-without-common-europeanidentity/\#.WwSFtyNWpSk

11. Debating Europe. October 29, 2017. Do you feel part of a common European identity? Retrieved on 02.06.2018 from: http://www.debatingeurope.eu/2013/10/29/do-you-feel-part-of-a-common-european-identity/ \#.WwSFxCNWpSk

12. Martinelli, A. November 2, 2017.The European Identity. University of Milan. Published online by "Globus et Locus". Retrieve on 2.06.2018 from: www.glocalismjournal.net

13. Project 28. 2018. Opinion on the EU. Retrieved on 2.06 .2018 from: http://project28.eu/opinions-on-theeu-2018/ 